In both the patients mentioned above the symptoms were those usually described as occurring in leakæmia, but it would perhaps be truer to say that in the case of the girl the splenic hypertrophy, following on anæmia, was a secondary affection; and that in the latter case, that of the male, there existed what was in effect a malignant disease of the spleen; so that in the former some good might be done by treatment, whilst in the latter such a result was not to be hoped for. I am indebted to Dr. Andrew for the information that he noticed a similar condition of the blood to the above in a boy under his care about four years ago, and in whom the disease proved fatal; also to $\mathrm{Mr}$. Hayward for similar information with regard to a case which occurred some time ago in the Westminster Hospital.

St. Bartholomew's Hospital.

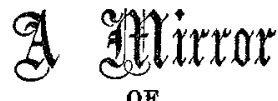

\section{HOSPITAL PRACTICE, BRITISH AND FOREIGN.}

Nulla autem est alia pro certo noscendi va, nisi quamplurimas et morborum et dissectionum historias, tum aliorum, tum proprias collectas habere, inter se comparare.-MorgaGNI De Sed.et Caus. Morb., lib.iv. Procmium.

\section{LONDON HOSPITAL.}

POPLITEAL ANEURISM ; PREPARATORY TREATMENT; COMPRESSION ; CURE ; REMARKS.

(Under the care of Mr. JoNathan Hutchinson.)

For the following notes we are indebted to Mr. F. Treves, F.R.C.S., surgical registrar.

This patient, a man fifty-seven years of age, was admitted into the hospital in December last with an aneurism in the right popliteal space. He was discharged about the middle of April as "cured," and presented himself a month later, according to instructions, in order that it might be seen whether the cure was permanent and complete. On exanination there was found in the popliteal space a trace of the old tumour, but it was very small and without the least sign of even the feeblest pulsation. Pulsation, however, was to be felt in the posterior tibial artery at the ankle, although not so distinctly as on the unaffected side. The case might, therefore, be considered one of perfect cure.

lemarks by Mr. HurchinsoN. -- With regard to the tumour itself there was nothing especial to note; it was a typical aneurism in every respect. The patient was a healthy, well-developed man of temperate and quiet habits, with no history of syphilis and no explanation to offer for the appearance of the tumour, except the frequent and often foreible movements to which his. Ieg wonld be subjected in following his employment as a carpenter. The aneurism was noticed ahout four weeks before admission, and was somewhat rapidly increasing in size.

To the treatment, however, of the case special attention should be drawn. Before any active measures for the cure of this aneurism were employed, the patient was subjected to the following preliminary treatment, which had previously been carried out in three cases with uniform success. 1st. He was kept in bed in a state of absolute rest. 2nd. His diet was limited as far as possible to solid food, a minimum of liquids only being allowed. The patient, having these instructions before him, and possessed with an intelligent desire to carry them out, managed to subsist on ten ounces of fluid per diem, or one pint in forty-eight hours. 3rd. Iodide of potassium was administered.

The perfect rest was of importance in so far as it acted by decreasing the arterial tension of the part and by preventing the aneurismal sac from being exposed to varying degrees of pressure. A diet composed as far as possible of solid foods, with but little liquid nourishment, aided considerably in increasing the fibrine of the blood, and so most favourably prepared the patient for the final and actual cure of the aneurism. The iodide of potassium was administered on account of the power it is presumed to possess of aiding the same process-viz., the increase of the blood fibrine. This action is, however, at present theoretical. This pre- paratory treatment was pursued for fourteen days. The only visible effect noticed was that the tumour, instead of continuing rapidly to increase, ceased at least to grow, and in fact diminished half an inch in circumference.

At the end of fourteen days the patient was anæsthetised, and Esmarch's elastic bandage and rubber band were applied to the limb. The bandage being removed, the band was kept on for one hour, the patient being under chloroform during that time. The limb was carefully watched during the process, and care was taken to prevent undue loss of temperature. Before the band was removed a number of dressers were ready at once to commence digital compression of the femoral artery in Scarpa's triangle. On the band being removed it was evident that the tumour still pulsated, but much less energetically than before. When digital compression had been applied for four hours all pulsation had entirely ceased in the tumour, but, as a matter of security, the pressure was continued for four hours longer. In a fortnight's time the patient left his bed, no trace of pulsation having been noticed since the day of the compression.

Of the two other cases referred to as having been subjected to this treatment, it may be remarked that in one the pulsation was found to have entirely ceased on the removal of Esmarch's band; while the other case was almost an exact counterpart of the present one. In both cases the cure was sound and permanent.

There are few, very few, cases of aneurism that cannot be cured by digital compression, if properly and intelligently applied, and presuming that compression be anatomically possible; and it is highly probable that that mode of treatment is much assisted by the preliminary procedure above indicated. Digital compression certainly requires a staff of good assistants, and is irksome to the patient; but it is nothing more than irksome; it is a simple and safe mode of cure, and should always have a most thorough trial before any more serious procedure is entertained.

\section{MIDDLESEX HOSPITAL.}

INTRA-UTERINE FIBROID TUMOURS OF UTERUS, SESSILE AND PEDICULATED, AS CAUSES OF UTERINE HÆMORRHAGE; TREATMENT FOR THEIR REMOVAL.

(Under the care of Dr. HAIL DAVIS.)

THE following case is from notes by Mr. W. E. Dixon, obstetric physician's assistant.

Fanny $\mathrm{R}-$ - aged forty-eight, married, was admitted, April 30th, 1879, into Prudhoe ward for uterine hæmorrhage. It was found to be dependent on an intra-uterine tumour, elevating the fundus nearly to the navel. She had had four labours at full term, the last ten years ago. She had not had any miscarriage. The hæmorrhages had been of three years' duration, but most profuse at her menstrual periods.

On admission, the patient had undergone the ordinary styptic treatment for hæmorrhage without permanent benefit. She was very exhausted and extremely anæmic; her lower extremities were cedematous, but there was no albumen in the urine, sp. gr. 1014. As she was not then losing blood, it was thought advisable, in view of operative treatment under more favourable circumstances, to rally the patient's strength first by tonic measures.

May 13th. - That object having been fulfilled, and no hæmorrhage of consequence having recurred in the interim, the connexions of the intra-uterine tumour were examined to-day. The depth of the uterine cavity, measured by the sound passed to the fundus, was found to be four inches and a half. Part of the tumour occupied the cervical canal, and was adherent to the cervix for three-fourths of its circumference.

The patient was now placed under anæsthesia, commencing with chloroform, afterwards carrying it on with ether. Dr. Davis then detached with the finger the adhesions to the interior of the neck of the uterus upwards, till the rest of the growth, as.high as could be reached, appeared free. He then passed up the loop of a wire-rope écraseur over the tumour till he supposed its advance was stopped by an adhesion. His next intention was at once to amputate the growth, but, the process being tedious, he decided, after he had partly crushed through it, to endeavour to remove the tumour by a combination of torsion and ex. tractive efforts. In this way the remaining not very firm 